\title{
Focus Structure in Persian Interrogative Sentences: An RRG Analysis
}

\author{
Vali Rezai ${ }^{1} \&$ Mozhgan Hooshmand ${ }^{1}$ \\ ${ }^{1}$ Linguistics Department, Faculty of Foreign Languages, University of Isfahan, Isfahan, Iran \\ Correspondence: Mozhgan Hooshmand, Linguistics Department, Faculty of Foreign Languages, University of \\ Isfahan, Isfahan, Iran. Tel: 98-917-738-3194. E-mail: hooshmandmozhgan@yahoo.com
}

Received: April 17, 2012 Accepted: May 10, 2012 Online Published: July 5, 2012

doi:10.5539/elt.v5n8p130 URL: http://dx.doi.org/10.5539/elt.v5n8p130

\begin{abstract}
The studies regarding information structure and its distribution in sentences are traced back to works of Prague School linguists such as Mathesius in 1920s. Recently, the issue of information structure has been dealt with by functionalists. In Role and Reference Grammar (RRG), information structure constitutes one of the main components of syntax. In this theory, information structure is mainly based on the Lambrechtiyan information structure which regards the formal structure of sentences as highly related to the discourse-pragmatic functions. Information structure investigates the way information is structured in clauses and sentences. This paper aims at dealing with information structure in interrogative sentences according to RRG. At first a brief introduction to works on information structure and RRG is presented. Then the theory is applied briefly to Persian language declaratives and dominantly to interrogatives.
\end{abstract}

Keywords: focus structure, functions, Persian, interrogatives, Role and Reference Grammar

\section{Introduction}

Persian, a verb-final Indo-Iranian language, is said to have some flexibility in the ordering of constituents within a sentence, however, it does not have a complete free word order and some constructions are more acceptable than others. Prague school linguists call the principles underlying the flexibility in word order the "functional sentence perspective (FSP)" (Mathesius, 1983). Mathesius (1929, p. 127), an early Prague School linguist, divided the parts of an utterance into "theme" and "rheme". The theme is what "one is talking about, the topic", and the rheme is "what one says about it, the comment".

As Rezai (2003a) states Lambrecht's information structure theory provides an alternative to Functional Sentence Perspective (FSP). In his theory of information structure, Lambrecht (1994) identifies TOPIC and FOCUS as the two primary information statuses. He divides a proposition into pragmatic presupposition and pragmatic assertion. The pragmatic assertion is "the proposition expressed by a sentence which the hearer is expected to know or take for granted as a result of hearing the sentence uttered" (p. 52). The pragmatic presupposition is "the set of propositions lexicogrammatically evoked in an utterance which the speaker assumes the hearer already knows or believes or is ready to take for granted at the time the sentence is uttered" (p. 52). The focus of the assertion is "the semantic component of a pragmatically structured proposition whereby the assertion differs from the presupposition" (p. 213). Thus, focus is a part of the assertion. It is a semantico-pragmatic category which creates the assertion when added to the pragmatic presupposition. Focus structure conventionally associates focus meaning with sentence form (p. 222). "The syntactic domain in a sentence which expresses the focus component of a pragmatically structured proposition" is the focus domain (p. 214). Pragmatic presupposition is similar to the FSP concept of theme. Rheme and focus are overlapping but not mutually inclusive concepts. Both rheme and focus are associated with the sentence final position in unmarked utterances.

Lambrecht (1994) suggests that the formal structure of sentences is related to the communicative situations in which sentences are used. He states that "this relationship is governed by principles and rules of grammar, in a component called information structure" (as cited in Rezai 2003a). In Lambrecht's theory, the unmarked placement for focused material is final. It is not always the final element in the sentence, but it can rather occur anywhere within the sentence, in which case it is regarded as marked position.

This paper tries to investigate information structure in interrogative sentences. However, instead of exploring it directly, at first the concepts of RRG is introduced through its application on Persian declaratives. In order to find focus in sentences, at first basic Lambrechtian paradigms are utilized. 


\section{Introduction to Role and Reference Grammar}

The analysis in this paper is based on a syntactic theory called Role and Reference Grammar, specially the version put forward in Van Valin's Exploring Syntax-Semantic Interface (2005). In this theory, sentences have a layered structure. It is based on two fundamental contrasts: between predicate and non-predicating arguments, on the one hand, and, among the non-predicating elements, between arguments and non-arguments, on the other. The primary constituent units of the clause are the 'nucleus', which contains the predicate (usually a verb), the 'core' which contains the nucleus and the arguments of the predicate, and a 'periphery' which subsumes non-arguments of the predicate (Van Valin 2005, p. 4). The core along with the periphery, which is adjunct material (usually PP's and adverbs), make up the clause. The clausal layer can also contain a pre-core slot (PrCS) and/or a post-core slot (PoCS), that are positions within the clause but outside the core. An example of an element occurring in a pre-core slot (PrCS) is a wh-NP in a wh-question in English such as, 'Who saw the thief?' The sentence level contains the clause level, as well as, potentially, a left- or right-detached position (LDP, RDP). These are positions containing elements, such as AdvP's or PP's set-off from the rest of the sentence by a pause or intonation break (p. 6). Each of the layers of the clause has some operators that is specific to it. Operators are grammatical categories, such as tense, aspect, and illocutionary force. Table 1 shows the various layers of the clause along with the operators which function at any level (from Van Valin 2005, p. 9).

Table 1. Layers of the clause and their operators

\begin{tabular}{ll}
\hline Layer & Operator \\
\hline Nucleus & aspect \\
& negation \\
& directional \\
Core & directionals \\
& modality \\
Clause & negation \\
& status \\
& tense \\
& evidentials \\
Sentence & illocutionary force \\
\hline
\end{tabular}

Focus in RRG, is determined using Lambrechtian paradigms. Three focus types are differenciated: predicate, sentence, and narrow focus. RRG further provides for a focus domain, the syntactic constituent in which the focus occurs (p. 75). The potential focus domain is the entire syntactic domain where focus may occur in a given language, while the actual focus domain is the part of the sentence that is actually in focus in a given construction. These can be equal or different. In Persian, like English, the potential focus domain is the whole clause (Rezai, 2003a).

In this theory, syntactic knowledge is stored in the form of constructional templates. The templates give the morphosyntactic, semantic, and pragmatic properties specific to a given type of construction. RRG provides a formal theory within which the structure of the sentences can be examined. Each construction entails a specific syntactic template associated with a focus structure. These syntactic templates show the layered structure of the sentence, and how the various constituents in the sentence fit together. This, combined with the focus structure, which includes both potential and actual focus domains, illuminates how the various constructions differ and why they are found to occur felicitously in different contexts. The framework offered by RRG which incorporates focus with syntactic structure will be used in this paper to examine various constructions in Persian.

\section{Declarative sentences}

Lambrecht (1994) divides focus into three types: narrow, predicate, and sentence. Narrow focus occurs when a single constituent is focused upon. Predicate focus, the universally unmarked type of focus structure, is a topic-comment structure where the comment or predicate is what is focused upon. In sentence focus, the entire sentence is being focused upon. Lambrecht illustrates these focus types in English, Italian, French, and Japanese.

\subsection{Predicate Focus}

Predicate focus is obtained when the predicate comments upon the topic.

1. Q: What happened to your car? 

A: a. My car/It broke DOWN.
English
b. (La mia macchina) si e\$ ROTTA.
Italian
c. (Ma voiture) elle est en PANNE.
French
d. (Kuruma wa) KOSYOO-si-ta.
Japanese

In the above example, the question concerns the addressee's car. This car forms the presupposition of the answer. The answer tells what happened to it, that 'it broke down', hence is the focus. We use these examples as the basis for comparison with Persian.

2. Q: mâšin -et či šode?

car-POSS-2sg what become

'What happened to your car?'

A: a. mâšin-am XARÂB šode.

car-POSS-1sg break down become-PAST-3sg

'My car broke down.'

b. XARÂB šode.

break down become -PAST-3sg

'It broke down.'

In Persian, overt subjects are often not expressed when the referent is presupposed. Omitted subjects can often easily be deduced by a listener because of the fact that the verbal morphology shows person and number agreement with the non-overt NP. Thus, the most natural way to express the answer to the question, what happened to your car, is to omit car. The subject might occur preverbally, but this sounded rather odd. Thus, (2a) seemed more natural than $(2 \mathrm{~b})$.

\subsection{Sentence Focus}

In order to elicit sentence focus, a question is asked in which the reply has no presupposition. For example, when asked, what happened? a speaker cannot assume any pragmatic presupposition when replying.

3. Q: What happened?
A: a. My CAR broke down.
English
b. Mi si e\$ rotta la MACCHINA.
Italian
c. J'ai ma VOITURE qui est en PANNE.
French
d. KURUMA ga KOOSYOO-si-ta.
Japanese

No presupposition is involved in the above. The subject of the sentence is not a presupposed one. Rather both subject and predicate are asserted. Thus, the reply is completely focus and wholly assertion.

Now, Persian can be examined to see what happens when the entire utterance is assertion and focus.

4. Q: či šode? 'What happened?'

\section{A: a.MÂŠIN-AM XARÂB šode.}

car-1sg POSS break down become-PAST-3sg 'My car broke down.'

* b. XARAB šode. 'It broke down.'

So, when a sentence is entirely asserted, the subject is always intonationally prominent (stressed). This differs from when the subject is presupposed, as in (2), where it was not stressed and preferrably omitted. Lambrecht(1994, p. 274) states that a constituent in focus cannot be omitted without depriving the utterance of some or all of its information value. In fact, subject in the above answers is not topic, so its omission results in infelicitous answer.

\subsection{Narrow Focus}

In contrast to sentence focus, narrow focus places a single constituent in focus. Such a situation may occur in answer to a question or when an interlocutor has created a statement which is correct except for one false constituent. An addressee replying to such an erroneous statement corrects the wrong constituent and, thus, focuses on this single constituent. 
A very common example of narrow focus sentence is a WH-question like What did you buy? and the answer I bought ; the WH-word and the NP filling its slot in the reply are both narrow focus.

Now, consider this example from Lambrecht:

5. Q: I heard your motorcycle broke down.
A: a. My CAR broke down.
English
b. Si e rotta la mia MACCHINA. /
Italian
E la mia MACCHINA che si e rotta.
c. C'est ma VOITURE qui est en panne.
French

In the above, only car is not presupposed. The focus, the unpredictable information added to the presupposition is car. In English, the focal car is given intonational prominence. Italian can postpose the subject or use a special cleft construction (5b). Each time, the subject is stressed.

Now, we consider the similar example in Persian:

6. Q: motor -et xarâb šode?

motorcycle-2sg POSS break down become-PAST-3sg?

'Has your motorcycle broken down?'

A: a. motor-am na, MÂŠIN -am

Motorcycle- 1sg POSS not, car-1sg POSS

b. na, MÂŠIN -am xarâb šode.

No, car-1sg POSS break down become-PAST-3sg.

'No, my car has broken down,

* c: xarâb šode MÂŠIN -am.

In these examples, the focus is given intonational prominence. In (6a) it occurs after the material given as pre-verbal (in its normal position). However, placement of subject after predicate is prohibited (6b), so this position is not within the actual focus domain in Persian.

Lambrecht (1994) distinguishes unmarked narrow focus from marked narrow focus, the difference being where the focus falls. In verb-final languages (like Persian) the unmarked focus position is the immediate preverbal position (Van Valin 2005, p.72).

In Persian transitive sentences, focus structure may affect the order of constituents (Rezai \& Tayyeb, 2006)

7. Q: ki livân-o šekast?

who glass-OBM break-PAST- 3sg

'Who broke the glass?'

A: a.ALI livân-o šekast. (SOV)

Ali glass-OBM break-PAST.3sg

'Ali broke the glass.'

b. livân-o ALI šekast. (OSV)

glass-OBM Ali break-PAST.3sg

* c. livân-o šekast ALI (OVS)

Glass-OBM break-PAST.3sg ALI

[râ is object marker and its allomorphs are $r o$ following a vowel and $o$ following consonants]

Here, narrow focus is on subject. The focal subject of a transitive sentence is placed either clause-initially as in (7a) or between the object and the verb as in (7b). Post-verbal focal subject as in (7c) is completely infelicitous, as it was the case in intransitive sentence.

Now, an example of focal object is considered:

8. Q: Ali či ro šekast?

Ali what OBM break-PAST- 3sg 
'What did Ali break?'

A: a. (Ali) LIVÂN-o šekast

Ali glass OBM break-PAST- 3sg

b. LIVÂN-o Ali šekast

glass OBM Ali break-PAST- 3sg

* c. Ali šekast LIVÂN-o.

Ali break-PAST- 3sg glass
'Ali broke the glass.'

The focal object of a transitive sentence is placed either in preverbal position (unmarked focus position) as in (8a) or clause-initially as in (8b). Again post-verbal focal object as in (8c) is infelicitous. Focus position in Persian is in-situ, that is, in preverbal position, or it can occur in initial position which is marked narrow focus (Rezai, 2003b). According to Roberts (2005) this position is pre-core slot. However, this position can only be occupied by specific object not non-specific one.

9. Q: Mahdi či xarid?

Mahdi what buy-PAST-3sg

'What did Mahdi buy?'

A: a. Mahdi KETÂB xarid.

Mahdi book buy-PAST-3sg

'Mahdi bought a book.'

* b. KETÂB Mahdi xarid.

book Mahdi buy-PAST-3sg

* c. Mahdi xarid KETÂB .

Mahdi buy-PAST-3sg book

In the above, the ungrammaticality of $(9 b)$ is due to the occurrence of non-specific object in marked focus position. (9c) is infelicitous, since it is post-verbal focal object. Karimi (2003, p. 93) considers these examples as constituent movement. However, she considers movement of specific object as an instance of scrambling which is itself a reflection of discourse information such as topic and focus. However, scrambling is not possible for non-specific object.

In sum, in Persian, predicate (unmarked) focus involves a stressed predicate and optional subject. Sentence focus places stress on the subject and does not allow for the omission of the subject because of its being focal. Narrow focus on the subject stresses it intonationally. Also, such subjects occur pre-verbally, both in-situ or in immediate preverbal position. Focal objects, too, receive stress and may occur in immediate preverbal position or initially. Neither focal element can occur post-verbally. Hence, intonational or prosodic prominence is always a correlate of focus in Persian, as it was for the other languages cited. Even, there are cases in which only stress is the indicator of focal element and it is possible for the focal stress to fall on any constituent of the sentence. For example in

Bačče ŠÂM-EŠ-o xord.

child dinner-POSS-3sg-OBM eat-PAST-3sg

'The child ate his dinner, not anything else.'

BAČČE šâm-eš-o xord

child dinner-POSS-3sg-OBM eat-PAST-3sg

'The child $\mathrm{i}$ ate his dinner, not anybody else'

In Persian, focus (information) structure is indicated syntactically by constituent order and prosodically by stress placement. All nouns and adjectives in Persian are stressed on the final syllable (Yarmohammadi 2002). Sentence stress in Persian, in unmarked case, falls on the element before the final verb. So, the unmarked focus position is pre-verbal position. Predicate focus is indicated when primary sentence stress falls on the last stressed syllable before an affirmative verb. 


\section{Interrogative Sentences}

\subsection{Yes-No Questions}

This section explores the various possibilities of focus placement within a yes-no (non-wh) question sentence in Persian. The possibilities of focus in the question are explored by looking at the possible felicitous replies. First, SOV word ordered questions are explored using intransitives, transitives and ditransitives. Then, non-SOV word orders are considered.

\subsubsection{SOV-ordered Yes-No Questions}

Now that focus in answers has been explored to a certain level of resolution, question structure must be examined. In order to elucidate where focus is placed in a question, the possible felicitous replies must be looked at. When asked, what are you eating?, the reply may include I am eating as in I am eating bananas, but the new information bananas is what makes it a valid reply; it is the focus. Thus, the plausible answers to a given question permit one to see what was exactly able to be focused upon (answered) in the question.

10. Q: Did John eat dinner?

A: a. No, Bob did.

b. No, he ate breakfast.

c. No, he bought it, but he didn't eat it.

In (10a), narrow focus is on the subject in the question. (10b), places narrow focus on the object. (10c) negates the assumed verb of the question. This is possible, since questions can have nuclear focus on the verb. Now, the same type of construction in Persian can be examined. First, a question and its replies are considered for a clause containing an intransitive predicate (11). (' $\hat{a} y \hat{a}$ ' is a question marker which is obligatory in written Persian.)

11. Q: (âyâ) SAMAN âvâz xând?

QM Saman song read-PAST-3sg?

'Did Saman sing?'

A: a. na, REZ âvâz xând.

no, Reza song read-PAST-3sg.

'no, Reza sang.'

b. na, u PIANO NAV XT.

no, he piano play-PAST-3sg

'No, he played the piano.'

c. na, REZ PIANO NAV XT.

no, Reza piano play-PAST-3sg

'No, Reza played the piano.'

The reply in (11a) negates the subject. This attributes marked narrow focus on the subject to the original interrogative. Or, the verb alone may be addressed in the reply, as in (11b). As, there are no objects or adjuncts, (11b) might be analyzed as involving either nuclear or predicate focus. Finally, a question like, Did John sing?, might be completely negated, focusing on each of the constituents in the clause (11c). Thus, any component of the sentence seems to be able to be focused upon in a yes-no question. Transitive sentences provide another level of complexity. (12) provides an example of a transitive yes-no question and its replies.

12. Q: (âyâ) Rezâ Maryam râ did?

QM Reza Maryam OBM see-PAST-3sg

'Did Reza see Maryam?'

A: a. na, bâ u TAM S GEREFT.

no, with she contact take-PAST-3sg.

'No, he called her.'

b. na, u MOHAMMAD râ did.

no, he Mohammad OBM see-PAST-3sg 
'No, he saw Mohammad.'

c. na, $\mathrm{S}$ R u râ did.

no, Sara she OBM see-PAST-3sg

'No, Sara saw her.'

* d. na, ALI bâ Maryam TAM S GEREFT.

no, Ali with Maryam contact take-PAST-3sg

'No, Ali called Maryam.'

e. na, Rezâ bâ MOHAMMAD TAM S GEREFT.

no, Reza with Mohammad cantact take-PAST-3sg

'No, Reza called Mohammad.'

The constituent most easily focused upon is verb, as in (12a). Narrow focus on 'Maryam' is also possible (12b), where the reply contradicts the object, providing a felicitous answer. Narrow focus upon the subject (12c) is also possible. Focus on both the subject and verb was not possible as shown by the infelicity of (12d). However, in (12e) focus on both the verb and indirect object is felicitous. It is likely due to pragmatic factors. It is hard to find a context where such answers would be natural.

Next, clauses with a ditransitive verb must be examined to further elucidate possible focus positions in the questions. Example (13) gives a ditransitive question and its answers.

13. Q: (âyâ) Roya mâšin-eš ro be Maryam qarz dâd?

(QM) Roya car-POSS-3sg OBM to Maryam debt give-PAST-3sg?

'Did Roya borrow her car to Maryam?'

A: a1. na, (u) mâšin-eš ro be Maryam FORUXT.

no, (she) car-POSS-3sg OBM to Maryam sell-PAST-3sg

a2. na, un ro beh-eš FORUXT.

no, it OBM to-she-OP sell-PAST-3sg

a3. na, be u FORUXT.

no, to she-OP sell-PAST-3sg

'No, she sold her car to her.'

b. na, REZ (mâšin-eš ro) be u qarz dâd.

no, Reza (car-POSS-3sg OBM) to she-OP debt give-PAST-3sg

'No, Reza borrowed his car to her.'

c. na, u beh-eš DOČARXE-AŠ ro qarz dâd.

no, he to-she-OP bicycle-POSS-3sg OBM debt give-PAST-3sg

'No, he borrowed his bicycle to her.'

d. na, un ro be $S$ R qarz dâd.

no, it OBM to Sara debt give-PAST-3sg

'No he borrowed it to Sara.'

The ditransitive question can be posited to have nuclear focus as marked by the contradiction of the verb (13a). All three answers in (13a) are felicitous. The subject, not being focal, can be omitted; direct or indirect objects may be replaced by a pronoun, since they are not within actual pocus domain. This question may also have marked narrow subject focus (13b), and marked narrow object focus (13c). Additionally, marked narrow focus can be placed on the indirect object, as in (13d). Indeed, the entire core is under the scope of potential focus as any argument or the nucleus may be focused upon.

So far, all of the single arguments have been examined. Example (14) examines the possibilities for focus with larger components within the core.

14. Q: (âyâ) Ali mâšin-eš ro be Maryam qarz dâd? 
(QM) Ali car-POSS-3sg OBM to Maryam debt give-PAST-3sg?

'Did Ali borrow his car to Maryam?'

A: a. na, (u) DOČARXE-AS̆ ro BE S R FORUXT.

no, (he) bicycle-POSS-3sg OBM to Sara sell-PAST-3sg.

'No, he sold his bicycle to Sara.'

b. (u) DOČARXE-AŠ ro beh-eš FORUXT.

no, (he) bicycle-POSS-3sg OBM to-she-OP sell-PAST-3sg.

'No, he sold his bicycle to her.'

c. na, (u) mâšin-eš ro be $S \quad R \quad$ FORUXT.

no, (he) car-POSS-3sg OBM to Sara sell-PAST-3sg.

'No, he sold his car to Sarah.'

d. na, (u) DOČARXE-AŠ ro be $\mathrm{S}$ R qarz dâd.

no, (he) bicycle-POSS-3sg OBM to Sara debt give-PAST-3sg.

'No, he borrowed his bicycle to Sara.'

e. na, REZ mâšin-eš ro beh-eš FORUXT.

no, Reza car-POSS-3sg OBM to-she-OP sell-PAST-3sg.

'No, Reza sold his car to her.'

f. na, REZ DOČARXE-AŠ ro beh-eš qarz dâd.

no, Reza bicycle-POSS-3sg OBM to-she-OP debt give-PAST-3sg.

'No, Reza borrowed his bicycle to her.'

g. na, REZ mâšin-eš ro be $S \quad R$ qarz dâd.

no, Reza car-POSS-3sg OBM to Sara debt give-PAST-3sg.

'No, Reza borrowed his car to Sarah.'

(14a) is a reply which implies focus on all the constituents within the predicate; the verb, its object, and the indirect object are all contradicted. It seems not so natural, because of the fact that so much information changed. Only in a very specific context might it serve as an answer.

Focus on the verb and either the direct object (14b) or the indirect object (14c) is also possible. Focus on both the direct and indirect objects is also felicitous (14d). (14e) shows that the verb and the subject can also be focused upon at the same time. In (14f), both subject and direct object are focused upon, while, in (14g) focus is on the subject and indirect object. In a ditransitive, two components (nucleus + argument $(14 \mathrm{~b}, \mathrm{c}, \mathrm{e})$ or argument + argument (14d)) can be negated in felicitous replies, while, only one component of a monotransitive (nucleus or argument) can be negated. However, study of actual spoken dialogue within context would probably regularize the data more. But with yes-no questions, the potential focus domain encompasses the entire core, restricted here only by pragmatic ability to relate the reply to the question.

It is appropriate to note that, in written formal Persian, yes-no particle "âyâ" is obligatory. Kahnemuyipoor (2001) regards its most common position as in clause initial; however, it can appear in other positions as well:

âyâ rais jomhur name râ be noxost vazir dâd?

QM president letter OBM to prime minister give-PAST-3sg

rais jomhur âyâ name râ be noxost vazir dâd?

president QM letter OBM to prime minister give-PAST-3sg

'Did the president give the letter to the prime minister?'

But, it cannot occur post-verbally, as in:

*rais jomhur name râ be noxost vazir dâd âyâ?

president letter OBM to prime minister give-PAST-3sg QM

Meshkatodini (1998) also provides other exaples to show the impossibility of question marker to be placed 
post-verbally:

*Ali be madrese raft âyâ?

Ali to school go-PAST 3sg QM

'Did Ali go to school?'

*Afshin ketâb-e tâze-i xarid magar? ('magar') is anoter yes-no question marker.)

Afshin book-GM new-IM buy-PAST-3sg QM

'Did Afshin buy a new book?'

As it was the case in declaratives, these examples also confirm the idea that there is no poet-verbal focus position in Persian.

\subsubsection{Non-SOV Ordered Yes-No Questions}

Now, non-canonically ordered, yes-no questions can be investigated. Canonical and non-canonical orders for an intransitive, yes-no question are given in (14).

15. a. (âyâ) Zohre âvâz xând?

(QM) Zohre song read-PAST-3sg?

b. (âyâ) âvâz xând Zohre?

(QM) song read-PAST-3sg Zohre?

'Did Zohre sing?'

The answers to (15a), provided in (11), included replies implicating either nuclear or marked narrow subject focus. The felicitous answer to (15b) is provided in (16).

16. a. na, (u) PIANO NAV XT.

no, (she) piano play-PAST-3sg

'No, she played the piano.'

* b. na, REZ âvâz xând.

no, Reza song read-PAST-3sg.

'No, Reza sang.'

(16) shows that the VS question may be interpreted as focusing on the nucleus, but not the subject, which according to Roberts (2005), occupies Post- Core slot. Thus, with yes-no questions in non-canonical order, the post-verbal or final position cannot be focus position.

Now, using a monotransitive verb, all possible orderings are given in (17).

17. a. (âyâ) Rezâ Maryam ro did? SOV

(QM) Reza Maryam OBM see-PAST-3sg

b. (âyâ) Maryam ro Rezâ did? OSV

(QM )Maryam OBM Reza see-PAST-3sg

c. (âyâ) Maryam ro did Rezâ? OVS

(QM )Maryam OBM see-PAST-3sg Reza

d. (âyâ) Rezâ did Maryam ro? SVO

(QM )Reza see-PAST-3sg Maryam OBM

'Did Reza see Maryam?'

(17a) gives canonical word order, whose replies were given in (12). (17b,c,d) indicate that all OSV, OVS, and SVO are grammatical.

The possible answers to (17b) can be as follows:

b. A: a. na, bâ u TAM S GEREFT. Nuclear focus

no, with she contact take-PAST-3sg

'No. he called her.' 
b. na, ALI u râ did.

Subject focus

no, Ali she OBM see-PAST-3sg

'No, Ali saw her.'

c. na, SARA râ did.

no, Sara OBM see-PAST-3sg.

Object focus

'No, he saw Sara.'

And those to (17c) are given below.

c. A: a. na, bâ u TAM S GEREFT.

Nuclear focus

no, with she contact take-PAST-3sg

'No. he called her.'

* b. na, ALI u râ did.

Subject focus

no, Ali she OBM see-PAST-3sg

'No, Ali saw her.'

c. na, SARA râ did.

no, Sara OBM see-PAST-3sg. Object focus

'No, he saw Sara.'

As it can be seen, in replie to (17c), subject cannot be focal, since it occurred post-verbally. However, (17d) allows only for nuclear focus and can only have this sentence as reply:

d. A: a. na, bâ u TAM S GEREFT. Nuclear focus

no, with she contact take-PAST-3sg

'No. he called her.'

* b. na, ALI u râ did.

Subject focus

no, Ali she OBM see-PAST-3sg

'No, Ali saw her.'

* c. na, $\mathrm{S} \mathrm{R}$ râ did.

no, Sara OBM see-PAST-3sg.

Object focus

'No, he saw Sara.

Since object is in post-verbal position, it cannot be focused.

In sum, both canonical and non-canonical yes-no questions show that while the potential focus domain of yes-no questions with SOV ordering is the entire core, in non-SOV ordered yes-no questions, a final focus position is not possible and yields infelicitous replies.

\subsection{Wh-questions}

This section examines wh-questions, beginning with one wh-word and continuing to multiple wh-word questions.

\subsubsection{Questions Involving a Single Wh-word}

Constructions containing wh-question words often differ fundamentally in their placement of focus from those without such wh-question words. The following gives an example of two questions in English, one with a wh-question word (18a) and one without (18b).

18. a. What did you eat?

b. Did you eat a sandwich?

The wh-object in (18a) occurs in initial position whereas the non-wh object in (18b) remains in its in-situ post-verbal position.

The following gives an example of a single wh-question word within a Persian sentence (19).

19. a. ki mord? 
who die-PAST-3sg?

* b. mord ki?

die-PAST-3sg who?

'who died?'

(19a) indicates that when the wh-word subject occurs sentence initially and is given prosodic prominence, the utterance is grammatical and has a similar meaning to the

English question using an initial wh-word. Simply reversing the order and placing the wh-word in post-verbal position with prosodic prominence is not grammatical (19b).

Below, the felicitous replies to the acceptable sentence(19a) is given. These answers allow one to see what was focal in the question.

20. Q: ki mord?

who die-PAST-3sg?

'who died?'

A: a. PIREMARD_E mord.

Oldman-DM die-PAST-3sg.

b. PIREMARD_E.

* c. mord PIREMARD_E.

die-PAST-3sg Oldman-DM.

'The old man died.'

(20) shows that the felicitous answer to a wh-question with wh-word subject fills in who the unknown subject is, 'The old man'. (20b) shows that only the subject is needed to be filled and wh-word alone is indeed the focus. Since subject is in focus, it cannot occur post-verbally (20c).

Here, other interrogative sentences questioning the subject are given:

21. a. ki ketâb ro xarid?

who book OBM buy-PAST-3sg?

'Who bought the book?'

* b. ketâb (ro) xarid ki?

book (OBM) buy-PAST-3sg who?

'Who bought a(/the) book?'

c. ki ketâb xarid?

who book buy-PAST-3sg?

'Who bought the book?'

* d. ketâb ki xarid?

book who buy-PAST-3sg?

'Who bought a book?'

e. ketâb ro ki xarid?

book OBM ki buy-PAST-3sg?

'Who bought the book?'

A question is grammatical and gives a wh-word interpretation if the wh-word subject is sentence initial (21a) and ungrammatical, if it is sentence final (21b). (21c) in which object is unspecified, has two readings, based on the placement of stress. If wh-word is stressed on, the sentence inquires the subject and it is a narrow focus on subject. Although, it can have a yes-no question interpretation as 'did anyone buy book', when the sentence has predicate focus and rising intonation. Unacceptability of (21d) compared to (21e) is due to the specificity of the object, i.e. when the object is specific, it may occur in topic position.

Now, wh-word objects are investigated. (22) shows the grammaticality of various placements of a wh-object. 
22. a. či (ro) xarid Ali?

what (OBM) buy-PAST-3sg Ali?

b. či ro Ali xarid?

what OBM Ali buy-PAST-3sg?

c. Ali či (ro) xarid?

Ali what (OBM) buy-PAST-3sg?

* d. či Ali xarid?

what Ali buy-PAST-3sg?

* e . Ali xarid či?

Ali buy-PAST-3sg what?

'What did Ali buy?'

In $(22 \mathrm{a}, \mathrm{b})$ the wh-word is sentence initial, and the sentence is grammatical, regardless of where the subject is in relation to the verb. (22c), in which there is in-situ narrow focus, may have different readings based on the intonation. If sentence has falling intonation and stress on wh-word, it has an interrogative reading, inquiring the object. However, when it is pronounced with rising intonation, it can be regarded as an echo question. In (22d), the object has limited distribution, because of its being unspecific (Karimi, 2003). So, its placement in initial position (marked narrow focus, as in declaratives) is prohibited. And finally, ungrammatically of (22e) is due to the fact that in Persian there is no focus position in post-verbal position.

The felicitous replies to grammatical questions (22a, b, c) are as follow:

A: a. Ali KET B (ro) xarid.

Ali book (OBM) buy-PAST-3sg.

b. KET B ro Ali xarid.

book OBM Ali buy-PAST-3sg.

c. KET B (ro) xarid.

book (OBM) buy-PAST-3sg.

d. KET B (ro)

book (OBM)

'Ali bought a/the book.'

So far, only argument wh-words have been considered. Before exploring the placement of a non-argument wh-word, that is, an adjunct, it should be noted that, in Kahnemuyipoor (2001) all post-verbal wh-adjuncts are said to exhibit movement to a pre-verbal position. This is a confirmation of the impossibility of the focused wh-word to be placed post-verbally. For example, consider this sentence:

23. Ali bâ Maryam ezdevâj kard, čon dust-aš dâšt.

Ali with Maryam marriage make-PAST-3sg because friend-her have-PAST-3sg.

'Ali married Maryam, because he loved her.'

The interrogative sentence, which inquires the reason (adjunct non-argument) is given in (24).

24. a. čerâ Ali bâ Maryam ezdevâj kard?

why Ali with Maryam marriage make-PAST-3sg?

b. Ali čerâ bâ Maryam ezdevâj kard?

Ali why with Maryam marriage make-PAST-3sg?

c. Ali bâ Maryam čerâ ezdevâj kard?

Ali with Maryam why marriage make-PAST-3sg?

* d. Ali bâ Maryam ezdevâj kard čerâ?

Ali with Maryam marriage make-PAST-3sg why?

'Why did Ali marry Maryam?' 
Thus, to be grammatical, a wh-adjunct must not be placed finally.

Following examples provide further justification for the ungrammaticality of final wh-word due to the lack of post-verbal focus position.

25. * a. âzâz xund ki?

Subject wh-word

song read-PAST-3sg who?

'Who sang?'

* b. To did-i kodum dust-et ro?

Object wh-word

You see-PAST-2sg which friend-POSS-2sg OBM?

'Which one of your friends did you see?'

* c. šomâ un ketâb ro xarid-id key?

Adjunct wh-word

You that book OBM buy-PAST-2pl when?

'When did you buy that book?'

*d. Rahâ magâle-aš ro nevešt čegune?

Adjunct wh-word

Raha article-POSS-3sg OBM write-PAST-3sg how?

'How did Raha write her article?'

\subsubsection{Multiple Wh-word Questions}

Now interrogative sentences containing two wh-words can be examined. (26) provides an example of such a construction using a transitive verb.

26. a. ki ki-o did?

who whom-OBM see-PAST-3sg?

* b. ki-o ki did?

whom-OBM who see-PAST-3sg?

'Who saw whom?'

c. ki kodum-o xarid?

who which-OBM buy-PAST-3sg?

* d. kodum-o ki xarid?

which-OBM who buy-PAST-3sg?

'Who bought which one?'

e. ki be ki ketâb dâd?

who to whom book give-PAST-3sg?

* f. be ki ki ketâb dâd?

to whom who book give-PAST-3sg?

'Who gave a book to whom?'

(26a, c, and e) show that only those questions are grammatical in which subject wh-word is placed initially and before direct or indirect object wh-word. Kahnemuyipoor (2001) considers it as an instance of superiority effect. However, here, the reason is that both subject and predicate can be focal. So, no element is allowed to be placed between predicate components (verb and object).

The felicitous answer to (26a) can be: 'Ali saw Maryam', 'Reza saw Sarah', ..., or 'Ali saw Maryam' in a situation when the speaker is repeating the sentence not understood or heard exactly on uttering by another person for the first time and wants to hear it one more time. These two type of readings are possible for (26c, e) as well.

Now, some other questions are provided.

27. * a. did ki-o ki?

see-PAST-3sg whom-OBM who? 
* b. did ki ki-o ?

see-PAST-3sg who whom-OBM?

* c. ki did ki-o ?

who see-PAST-3sg whom-OBM?

$*$ d. ki-o did ki?

whom-OBM see-PAST-3sg who?

'Who saw whom?'

Example (27) points out that sentences which place any of the wh-words finally are ungrammatical in Persian. Therefore, in order to obtain a wh-word reading, none of the wh-words must occur finally.

(28) tests the grammaticality of various word orders when an adjunct wh-word and an argument wh-word are used in the question.

28. a. ki četowr âvâz xund?

who how song read-PAST-3sg?

* b. četowr ki âvâz xund?

how who song read-PAST-3sg?

'Who sang how?'

c. Ali ki-o kojâ did?

Ali whom-OBM where see-PAST-3sg?

?? d. Ali kojâ ki-o did?

Ali where whom-OBM see-PAST-3sg?

* e. Ali did kojâ ki-o?

Ali see-PAST-3sg where whom-OBM?

* f. Ali did ki-o kojâ?

Ali see-PAST-3sg whom-OBM where?

When a question has two wh-words and one is an adjunct, grammatical readings are obtained when the argument wh-word is placed before the adjunct wh-word $(28 \mathrm{a}, \mathrm{c})$ but, If the adjunct precedes the argument, it is ungrammatical or at least less grammatical $(28 \mathrm{~b}, \mathrm{~d})$. In (28b) subject is placed after adjunct and in (28d), it is the object that is placed after adjunct. So, only arguments can precede adjuncts, not vice versa. Also, neither argument nor adjunct may occupy final position $(28 \mathrm{e}, \mathrm{f})$.

Now, ditransitives are examined in a sentence with four elements where both the direct and indirect objects are wh-words (29). Due to the number of possible orders of a four element sentence, the orderings will be divided in groups according to the placement of the wh-words - both initial $(29 a, b)$, one initial and one medial $(29 c, d)$, both medial with either order(29e,f), and both final $(29 \mathrm{~g}, \mathrm{~h})$.

29. a. či ro be ki dâd (Ali)?

what-OBM to whom give-PAST-3sg?

b. be ki či ro dâd (Ali)?

to whom what-OBM give-PAST-3sg?

c. či ro Ali be ki dâd?

what-OBM Ali to whom give-PAST-3sg?

d. be ki Ali či ro dâd?

to whom Ali what-OBM give-PAST-3sg?

e. Ali či ro be ki dâd?

Ali what-OBM to whom give-PAST-3sg?

f. Ali be ki či ro dâd?

Ali to whom what-OBM give-PAST-3sg? 
* g. Ali dâd be ki či ro?

Ali give-PAST-3sg to whom what-OBM?

* h. Ali dâd či ro be ki?

Ali give-PAST-3sg what-OBM to whom?

'What did Ali give to whom?'

Only questions with both wh-words occurring finally are ungrammatical when the subject is in initial position $(29 \mathrm{~g}, \mathrm{~h})$. Also, no sentences are felicitous when the subject is final and one wh-word is initial and one medial $(29 \mathrm{i}, \mathrm{j})$.

* i. be ki dâd či ro Ali?

to whom give-PAST-3sg what-OBM Ali?

* j. či ro dâd be ki Ali?

what-OBM give-PAST-3sg to whom Ali?

The infelicitous cases involved either placing both wh-words $(29 \mathrm{~g}, \mathrm{~h})$ or one $(29 \mathrm{i}, \mathrm{j})$ post verbally. In neither of felicitous cases dose the order of the direct and indirect objects make a difference.

So far, some types of multiple wh-questions have been seen in Persian. Subject can only occur initially and cannot follow either object or adjunct wh-word in the sentence. Adjunct wh-words can precede neither subjects nor object. Also, both direct and indirect object wh-word can occur initially and medially in any order. The common observation in all cases is the impossibility of any wh-word occurring post-verbally.

Now, sentences containing three wh-words can be examined. It should be noted that although such sentences are possible in Persian, they are quite rare.

30. a. ki či ro be ki dâd?

who what-OBM to whom give-PAST-3sg?

b. ki be ki či ro dâd?

who to whom what-OBM give-PAST-3sg?

* c. či ro ki be ki dâd?

what-OBM who to whom give-PAST-3sg?

* d. be ki ki či ro dâd?

to whom who what-OBM give-PAST-3sg?

'Who gave what to whom?'

Where all three of the wh-words occur initially, the only ungrammatical order is to place subject after direct or indirect object $(30 \mathrm{c}, \mathrm{d})$. However, in grammatical sentences $(30 \mathrm{a}, \mathrm{b})$, the order of direct and indirect object does not matter.

* e. dâd be ki ki či ro?

give-PAST-3sg to whom who what-OBM?

* f. dâd či ro be ki ki?

give-PAST-3sg what-OBM to whom who?

* g. dâd či ro ki be ki?

give-PAST-3sg what-OBM who to whom?

In all cases where all the wh-words occur finally and the verb initially, sentences are ungrammatical.

In sum, wh-word questions were found in these ways: all wh-words could be placed sentence initially and they could occur in other positions as well. However, they could not occupy final position after the verb. For multiple wh-word questions, the wh-word which must be placed before the other ones followed this hierarchy:

$$
\text { subject }>\text { direct object, indirect object }>\text { adjunct. }
$$

\section{Conclusion}

This study attempted to provide a comprehensive account of focus structure in Persian interrogative sentences. To this end, at first declarative sentence information structure was explored. In order to examine focus structure 
in interrogatives, felicitous replies were provided. The RRG analysis of data accounted for both yes-no and wh-interrogatives, with their fundamental differences from declaratives.

In yes-no questions, both canonical and non-canonical yes-no questions showed that while the potential focus domain of yes-no questions with SOV ordering was the entire core, in non-SOV ordered yes-no questions, a final focus position is not possible and yields infelicitous replies.

The analysis of wh-questions revealed that all wh-words could be placed sentence initially and they could occur in other positions exept in final position after the verb. Also, a hierarchy of subject $>$ direct object, indirect object $>$ adjunct was organized for the wh-words which must be placed before the other ones in multiple wh-word questions. Transitivity does not govern word order in Persian by itself. Word order is determined by the information structure of sentences.

As Van Valin (1998) mentions, both yes-no and wh-questions are kinds of focus construction, often narrow focus, and accordingly, the focus of yes-no question or wh-expression must be interpreted as being within the actual focus domain. Actually, wh-words are the most prominent element of the sentence and receive the main stress (Rezai, 2003b).

On the whole, this study shows the importance of the syntax, semantics and pragmatics interface. It demonstrates the interaction of form and function in language. The findings show that syntax and semantics must be integrated with information structure, in order to provide a comprehensive account of facts found in languages.

\section{Acknowledgments}

The authors are indebted to the native speakers who were consulted to check the grammaticality of sentences.

\section{References}

Halliday, M. (1985). An introduction to functional grammar (2nd ed.). London: Edward Arnold.

Kahnemuyipoor, A. (2001). On WH-questions in Persian. Canadian Journal of Linguistics, 46(1/2), 475-523.

Karimi, S. (2003). On scrambling in Persian. In S. Karimi. (Ed.), Word order and scrambling. Oxford: Blackwell Publishers. http://dx.doi.org/10.1002/9780470758403

Lambrecht, K. (1994). Information structure and sentence form: A theory of topic, focus, and the mental representations of discourse referents. New York: Cambridge University Press.

Mathesius, V. (1983). Functional linguistics. In J. Vachek. (Ed.), Praguiana (pp. 121-42). Amesterdam: John Benjamins.

Meshkatodini, M. (1998). Movement of WH-constituent in Persian and its theoretical consequences. Proceedings of the Third Linguistics Conference, 127-148.

Rezai, V. (2003a). A role and reference grammar analysis of simple sentences in Farsi (Modern Persian). Ph. D. diss. Isfahan: Isfahan University. http://www.wings.Buffalo.edu.rrg

Rezai, V. (2003b). Pragmatics of interrogative sentences in Persian. Journal of Linguistics, 36, 59-78.

Rezai, V., \& Tayyeb, S. M. T. (2006). Information structure and ordering of sentence constituents. Journal of Grammar, 2, 3-19.

Roberts, J. R. (2005). Scrambling in Persian: An RRG approach. Retrieved from http://www.wings.Buffalo.edu.rrg

Van Valin, R. D. (1998). The acquisition of WH-questions and the mechanisms of Language acquisition. Retrieved from http://www.wings.Buffalo.edu.rrg.s

Van Valin, R. D. (2005). Exploring syntax-semantics interface. Cambridge: Cambridge university Press.

Yarmohammadi, L. (2002). A contrastive analysis of Persian and English. Tehran: Payam noor University.

\section{Appendix A: List of Abbreviations}

$\begin{array}{llll}\text { S } & \text { subject } & \text { V } & \text { verb } \\ \text { O } & \text { object } & \text { OBM } & \text { object marker } \\ \text { OP } & \text { object pronoun } & \text { PAST } & \text { past tense } \\ \text { POSS } & \text { possessive pronoun } & \text { QM } & \text { question marker } \\ \text { IM } & \text { indefinite marker } & \text { DM } & \text { indefinite marker } \\ \text { GM } & \text { genitive marker } & & \end{array}$

